\title{
Laboratory Test Date
}

National Cancer Institute

\section{Source}

National Cancer Institute. Laboratory Test Date. NCI Thesaurus. Code C83028.

The date on which the laboratory test occurred. 